\title{
The image of contemporary architecture of Wrocław depicted in recent tourist commercial and Internet media
}

\author{
Natalia Bursiewicz \\ Pedagogical University of Krakow \\ natalia.bursiewicz@up.krakow.pl \\ https://orcid.org/0000-0002-2037-0100
}




\section{Abstract}

The aim of the paper is to present the tourist and image potential of contemporary public architecture.

Wrocław was chosen as the research subject, as it is a historical center with an extremely rich architectural heritage, which has enjoyed great interest among visitors for centuries. With the announcement of Wrocław as the European Capital of Culture 2016, and then the European Best Destination in 2018, its attractiveness increased significantly, which was reflected not only in the number of visitors, but also in the advertising materials themselves.

Both before and after arrival, millions of tourists encounter a multitude of various advertising forms, both virtual and printed, which determine the direction of sightseeing and shape a specific image and perception of the city. In general opinion, Wrocław is considered a historic city, the most interesting places of which are concentrated around the Old Town and Ostrów Tumski. The Centennial Hall, built at the beginning of the 20th century, stands out from the „newer heritage".

The idea of the study, however, was to answer the question whether contemporary architecture is used in any way in the current tourist advertisement of the city. Another goal was to identify and list the most frequently appearing objects from the adopted group, and to analyze the manner of their presentation. Based on the collected materials, efforts were made to assess the role of the media in creating a tourist product in terms of promoting local architecture in recent years.

At the same time, an attempt was made to evaluate the role of architecture in creating the city's progressive brand. In the research, the author used the method of analyzing the existing statistical data, iconographic research and the method of analyzing the content of advertising materials, as well as scientific studies on cultural heritage and tourism in the city. The final part of the paper shows that modern architecture can be a significant element increasing the tourist attractiveness of the city.

Keywords: Contemporary architecture; Wrocław; city branding; architectural tourism

\section{Resumen}

El objetivo del trabajo es dar a conocer el potencial turístico y de imagen de la arquitectura pública contemporánea.

Se eligió Wrocław (Breslavia) como tema de investigación, ya que es un centro histórico con un patrimonio arquitectónico extremadamente rico, que ha gozado de gran interés entre los visitantes durante siglos. Con el anuncio de Breslavia como Capital Europea de la Cultura 2016, y luego Mejor Destino Europeo en 2018, su atractivo aumentó significativamente, lo que se reflejó no solo en el número de visitantes, sino también en los propios materiales publicitarios.

Tanto antes como después de la llegada, millones de turistas se encuentran con una multitud de diversas formas de publicidad, tanto virtuales como impresas, que determinan la dirección de la visita turística y dan forma a una imagen y percepción específicas de la ciudad. En general, Wrocław se considera una ciudad histórica, cuyos lugares más interesantes se concentran alrededor del casco antiguo y Ostrów Tumski. El Salón del Centenario, construido a principios del siglo XX, se destaca del "patrimonio más nuevo".

La idea del estudio, sin embargo, era responder a la pregunta de si la arquitectura contemporánea se utiliza de alguna manera en la publicidad turística actual de la ciudad. Otro objetivo fue identificar y enumerar los objetos que aparecen con más frecuencia del grupo adoptado 
y analizar la forma de su presentación. A partir de los materiales recopilados, se ha trabajado para evaluar el papel de los medios de comunicación en la creación de un producto turístico en términos de promoción de la arquitectura local en los últimos años.

Al mismo tiempo, se intentó evaluar el papel de la arquitectura en la creación de la marca progresista de la ciudad. En la investigación, el autor utilizó el método de análisis de los datos estadísticos existentes, la investigación iconográfica y el método de análisis del contenido de los materiales publicitarios, así como los estudios científicos sobre el patrimonio cultural y el turismo en la ciudad. La parte final del trabajo muestra que la arquitectura moderna puede ser un elemento significativo que incremente el atractivo turístico de la ciudad.

Palabras clave: Arquitectura contemporánea; Wrocław; marca de la ciudad; turismo arquitectónico

Resum:

L'objectiu del treball és presentar el potencial turístic i d'imatge de l'arquitectura pública contemporània.

Es va escollir Wrocław com a tema d'investigació, ja que es tracta d'un centre històric amb un patrimoni arquitectònic extremadament ric, que ha tingut un gran interès entre els visitants durant segles. Amb l'anunci de Wrocław com a capital europea de la cultura 2016 i després la millor destinació europea el 2018, el seu atractiu va augmentar significativament, cosa que es va reflectir no només en el nombre de visitants, sinó també en els propis materials publicitaris.

Tant abans com després de l'arribada, milions de turistes es troben amb multitud de formes publicitàries, tant virtuals com impreses, que determinen la direcció del turisme i configuren una imatge i percepció específiques de la ciutat. En general, Wrocław és considerada una ciutat històrica, els llocs més interessants dels quals es concentren al voltant del nucli antic i Ostrów Tumski. El Centennial Hall, construït a principis del segle XX, destaca del "nou patrimoni".

La idea de l'estudi, però, era respondre a la pregunta de si l'arquitectura contemporània s'utilitza d'alguna manera en la publicitat turística actual de la ciutat. Un altre objectiu era identificar i enumerar els objectes que apareixen amb més freqüència del grup adoptat i analitzar la manera de presentar-los. A partir dels materials recollits, es van fer esforços per avaluar el paper dels mitjans de comunicació en la creació d'un producte turístic en termes de promoció de l'arquitectura local en els darrers anys.

Al mateix temps, es va intentar avaluar el paper de l'arquitectura en la creació de la marca progressiva de la ciutat. En la investigació, l'autor va utilitzar el mètode d'anàlisi de les dades estadístiques existents, la investigació iconogràfica i el mètode d'anàlisi del contingut de materials publicitaris, així com estudis científics sobre el patrimoni cultural i el turisme a la ciutat. La part final del document mostra que l'arquitectura moderna pot ser un element significatiu que augmenta l'atractiu turístic de la ciutat.

Paraules clau: Arquitectura contemporània; Wrocław; marca de ciutat; turisme arquitectònic 


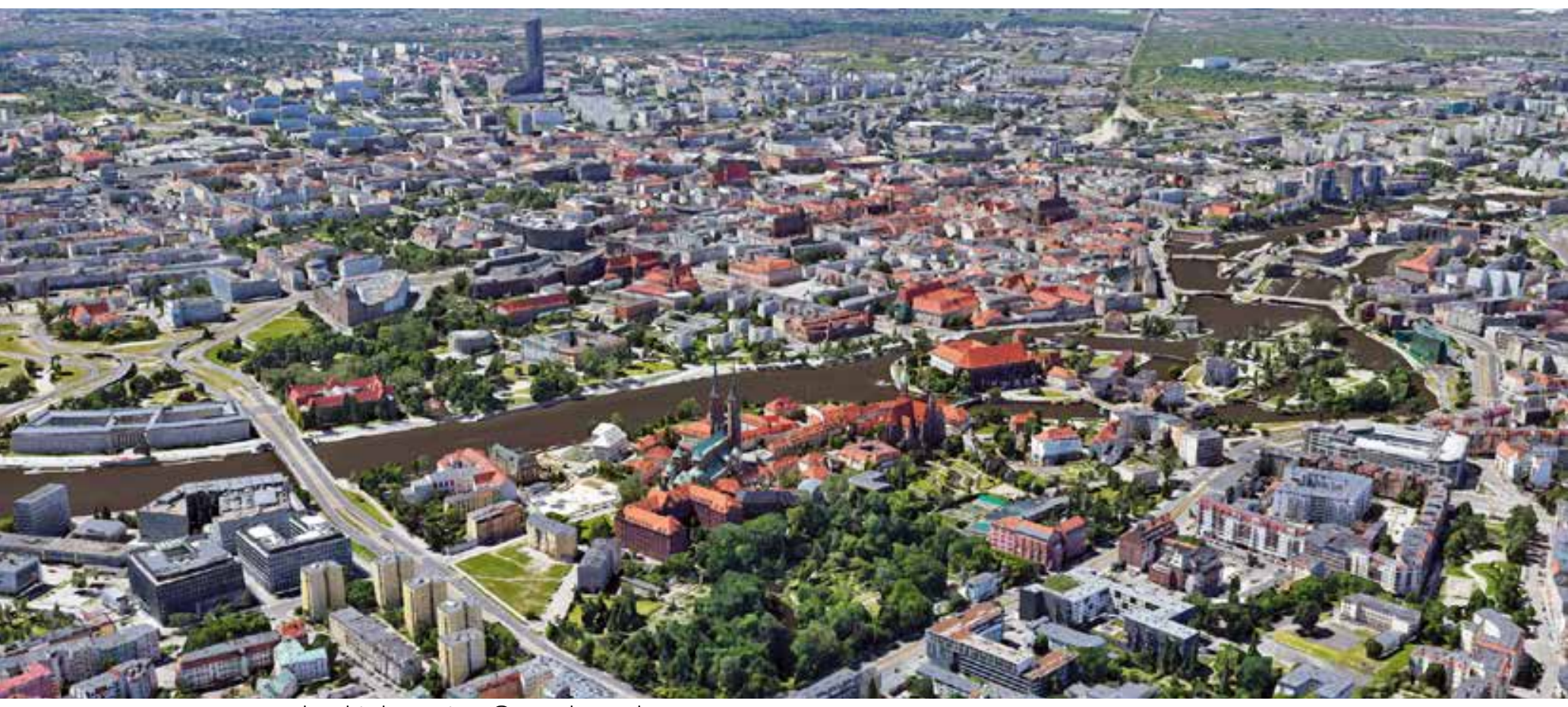

Wrocław bird eye view (C) Google Earth

The city can be treated as a book, but a special book, a kind of diary written over the centuries. Building elements can be compared to letters and words, buildings to sentences, and the city to stories. Each generation adds something of itself to this plot, tries to start the story from scratch, and sometimes rewrites old texts in its own way (Jałowiecki 2007: 152).

\section{Introduction}

Each city has some distinctive features that distinguish it from other cities (Adamus $\&$ Dzik 2019). These are, in terms of marketing, the resources influencing the attractiveness of the center. This is by no means a new concept. As the history of urban planning shows, the city has always been an undertaking aimed at bringing a specific result, benefit and profit. This was achieved in a variety of ways and on many levels. Nevertheless, architecture played a special and very important role in this case. It testified to the city's power and the wealth of its founders and rulers. It was a symbol of technological progress, economic development and aesthetic awareness. From both an architectural and a branding perspective, buildings were understood and perceived as symbols of 'good taste', 'power' and 'status' (Berg \& Kreiner, 1990).

With time, architecture also began to function as a tourist attraction. Cities and governments, throughout history, used consciously architecture in their promotion (Kavaratzis \& Ashworth, 2005; Anholt, 2010). With the popularization of the Grand Tour ${ }^{1}$,

1.- Editor's Note. The Grand Tour was popularized exclusively among the ruling classes. In this sense we cannot establish a continuity between the Grand Tour and the phenomenon of mass tourism that will be possible from the middle of the 19th century with the creation of rail networks, navigation powered by steam and the great appeal of the World Expos, especially since the last third of the 19th century. It is at this time that the need to 'attract foreigners' appears on the agenda of local and national policies, in a cultural context in the which 'heritage preservation' (Riegl 1903; Sitte 1889) is becoming dominant in Europe.(Remesar 2016, 2020) 


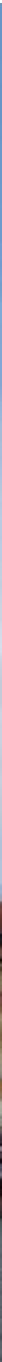

Main Marquet Square with Town Hall in the center, Wrocław, 2021, photo: N.Bursiewicz

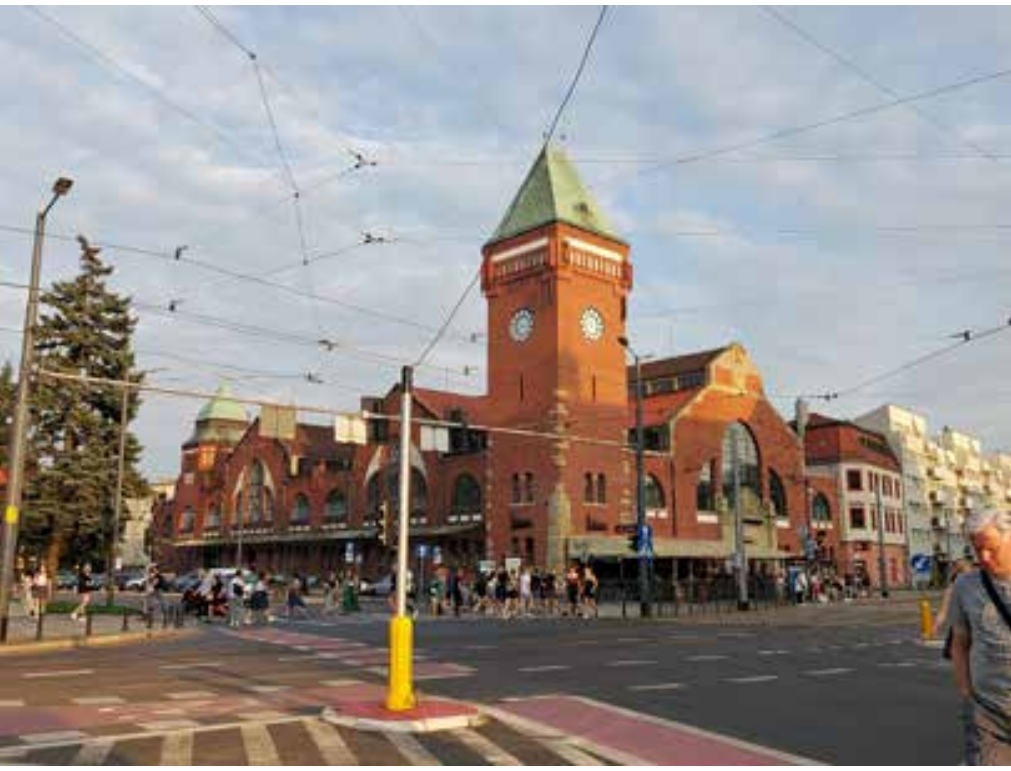

Marquet hall, Wrocław, 2021, photo: N.Bursiewicz

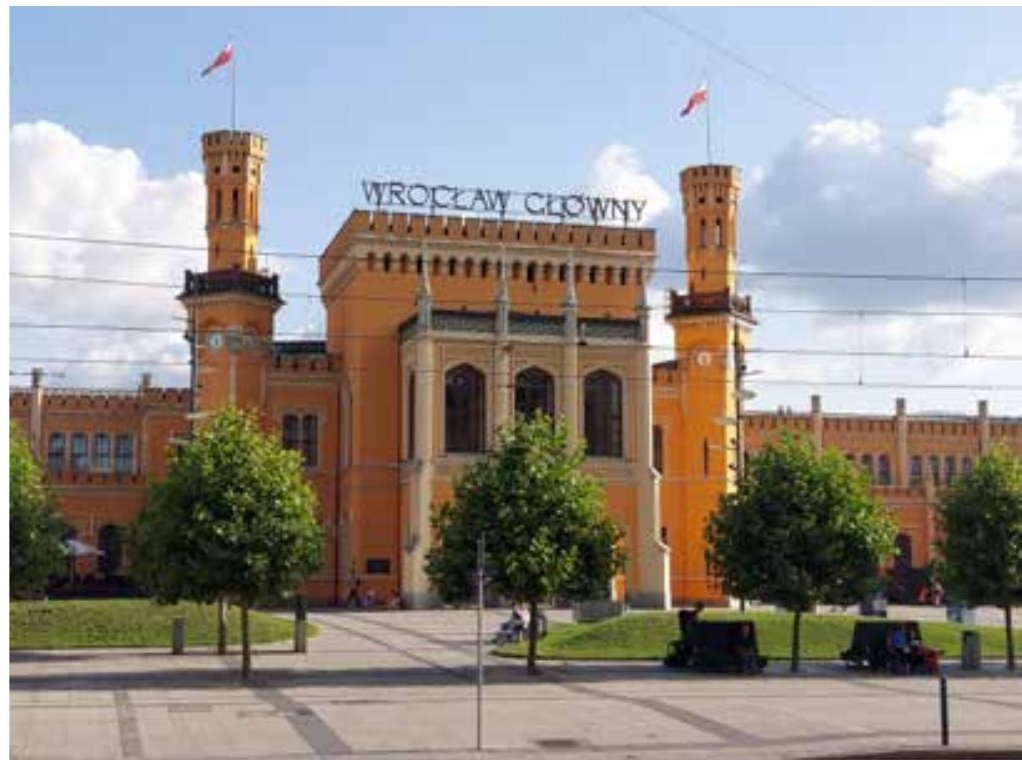

Railway station , Wrocław, 2021, photo: N.Bursiewicz 
knowledge of architecture and art became a sine que non element of every educational journey. Since then, consistently, despite the development of mass tourism, the cultural heritage has attracted masses of users, providing them with entertainment and unforgettable experiences. Thus, cultural tourism has become a priority image product of many European cities. It was no different in the case of Wrocław, although its popularity as a strictly tourist center began to grow only after the demolition of the city walls, and successively with the reconstruction and modernization of the city carried out in the 19th century. As a result, the extremely rich history and architectural heritage of this medieval city were exposed, restoring its monuments and at the same time introducing urban and architectural solutions matching the great European capitals of that time.

Wrocław, destroyed in 65 percent as a result of Second World War, has been rebuilding itself over the years, fighting for a higher and higher position both on the national and international market. With the announcement of Wrocław as the European Capital of Culture 2016, and then the European Best Destination in 2018, its attractiveness has increased significantly, which was reflected not only in the number of visitors, but also in the advertising materials themselves.

In common opinion, Wrocław is considered a historic city, the most interesting places of which are concentrated around the Old Town and Ostrów Tumski. The Centennial Hall, built at the beginning of the 20th century, is also highly admired. But what is the role of contemporary architecture? Is it used in any way in the current tourist advertisement of the city? Could it be a popular tourist attraction? The above-mentioned issues became the starting point for research on the image and tourism potential of the city's contemporary architecture. For this purpose, in the first stage, empirical research was carried out, consisting in searching, collecting and studying the literature on the subject, analyzing descriptive sources, and the content of advertising and statistical materials. Based on the collected material, an attempt was made to assess the role of the media in creating a tourist product in terms of promoting local architecture in recent years. The idea was also to evaluate the role of architecture in creating the city's progressive brand.

The article shows that modern architecture can be a significant element increasing the tourist attractiveness of the city. It can as well significantly influence the shaping of the image of Wrocław. The conducted research allowed to formulate some proposals for the future promotion of the city. Consequently, in addition to the theoretical and cognitive aspect that seeks to contribute to the academic discussion on city branding, this article may also have application significance, as it can be used in the preparation of different advertising forms- virtual and printed by the advertising agencies responsible for shaping a positive image of the city. 


\section{Architecture as a brand of the city}

Buildings that played the role of symbols, icons, clear spatial distinguishing marks appeared in every historical period. From the Egyptian pyramids, through Greek temples, Roman aqueducts, medieval cathedrals, renaissance palaces, baroque churches, classicist public buildings, and then factories of the industrial revolution, to 20th-century deconstructivist museums. They were not only to perform a specific function, but also to be a precise message, an expression of a sense of aesthetics, the latest construction achievements, the power and vision of the ruling class. Owing to the fact, as highlighted in the Leipzig Charter on Sustainable European Cities 2007, European cities possess unique cultural and architectural values. The problematic issue, due to its often controversial appearance and low quality, is the architecture of the 21st century. This is reflected in the mentioned Leipzig Charter, which clearly emphasizes the need to maintain a high standard of building culture.

The concern about the quality of architecture is related to the change in the approach to construction that has been progressing since the 20th century, when the aesthetic and functional idea began to be replaced by the glitter, size and scale of media influence. Architecture was then to be above all notable and noticeable, be seen and talked about (Ashworth 2009:14). This concept seems to be systematically deepening and gaining popularity. Especially that the rivalry between cities, intensified by e.g. globalization, is more and more fierce and demanding, which in turn forces the search for new solutions in many areas, including as part of investments and creative industry strategies. It is already proven, cities only achieve a competitive advantage when they have resources that are unique or difficult to imitate (Florek 2013, 45). These include, among others visual means of expression. Hence, architecture, fully consciously, was elevated to the rank of a means of enriching the tourist offer and the image of the city. According to the research, in Poland, every third city builds its image using its cultural heritage (Glinska et al. 2009: 29). This is in line with S. Anholt's national brand hexagon model, according to which culture and heritage have a significant impact on improving the reputation of a given center (Anholt, 2007: 39-40).

Well-groomed, visually attractive architecture becomes a captivating scenery that encourages multi-sensory perception, watching and admiring. As Yi-Fu Tuan suggests, great architecture continues to offer the most direct route out of our mundane experience, and so it will continue to be a destination for 21 century pilgrims (Ockman et. al. 2005: 11). It is therefore not surprising that cities are seeking to raise funds for revitalization, but also to take risks and invest in flagship buildings. They are tempted by a vision of international recognition, originality and photographic nature. Through a complex positioning process, buildings begin to be identified with a given locality (Corbos \& Popescu 2011: 305). However, in order to be called icons, they must meet 


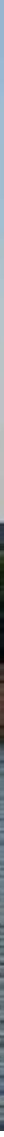

Ostrów Tumski with the cathedral on the right, Wrocław, 2021, photo: N.Bursiewicz

certain criteria. These include, among others uniqueness, ease of adaptation to a graphic symbol (logo), authenticity, noticeability, identification (see Rouba 2012). Objects with such features, through their individuality, distinguish the city from the competition. They become part of a campaign promoting a given area, which can be extremely effective.

On the other hand, their spectacularity and uniqueness don't often correspond with quality or timeless value. Many expensive spectacular buildings are more 'white elephants' than 'flagships' - as noted by Gregory J. Ashworth. As a result, they become shells that can quickly lose their meaning and can be easily replaced with another, even more attractive form. No wonder that such investments raise doubts as behind a popularity and "fireworks" there is a small value. The quality of the architecture should therefore be of key importance. Only then can it become an effective tool for creating the city's image and a unique tourist product (Temelova, 2004). This was aptly put forward by Mitchell Schwarzer, according to whom buildings can be "the boldest 
signature of urban identity that stand out from their surroundings and lent their cities the glamour of instant recognition and allure" (Schwarzer 2005: 25).

\section{The tourist potential of Wrocław in the context of architecture}

Wrocław, located in south-west Poland, received city rights in 1261. For centuries, as a Polish, Czech (1335), Austrian (Habsburg) (1526), Prussian/German (1741-1945), Polish (after 45) city, it played a key role as a center of trade, administration, industry, culture and education. Such a centuries-old variety of determinants reflected on the urban and architectural image of the city, translating into its originality and distinctiveness. It also influenced the multicultural nature of the city. Probably, that is why in 1997, after a visit to Wrocław, the then Pope John Paul II called it "the city of meeting". The formula became for years a recognizable slogan used in the promotion and marketing of Wrocław. However, the city had to prepare itself correspondingly for such direction. The appropriate setting played a significant role in this case, i.e. the broadly understood aesthetic, architectural and urban aspect, on which the city authorities put special emphasis. Thanks to this, when in 2000 the city celebrated the thousandyear jubilee of its existence, it was able to show its new, modernized image, which had an impact on the international arena, and then enabled the organization of international events attracting crowds of tourists and investors.

A clear impulse for the city's development were international sports and cultural events, such as the European Football Championship 2012 (that constituted an important trigger for infrastructural investments like the main train station, the airport, the city bypass highway, Wrocław 2016 European Capital of Culture (that aimed at making the city a true contemporary meeting point for diverse cultures and people as well as restoring the presence of art, culture and beauty in public (Ponzini et. al. 2020: 103, 108-109), UNESCO World Book Capital 2016, The World Games 2017 (which translated into greater recognition of the capital of Lower Silesia and increased interest in the city and the entire region, according to the Polish Tourist Organization [www. europeanbestdestinations.com]. Moreover, in 2019 Wrocław was part of the UNESCO Creative Cities Network. Thanks to the above events, as well as other promotional activities undertaken by the Office in the field of tourism promotion, the attractiveness of the city has definitely increased. This is also confirmed by the surveys carried out to verify the effects of the European Capital of Culture. According to the expectations and perceptions of Poles, such events reinforced Wrocław's image and become an impulse strengthening the city's development potential (Pluta et. al. 2017: 21). According to the data of the Central Statistical Office, the number of tourists visiting in 2018 was 1.3 million, placing Wrocław in the third place among the largest cities in Poland (Raport o stanie GMiny 2019: 150). 


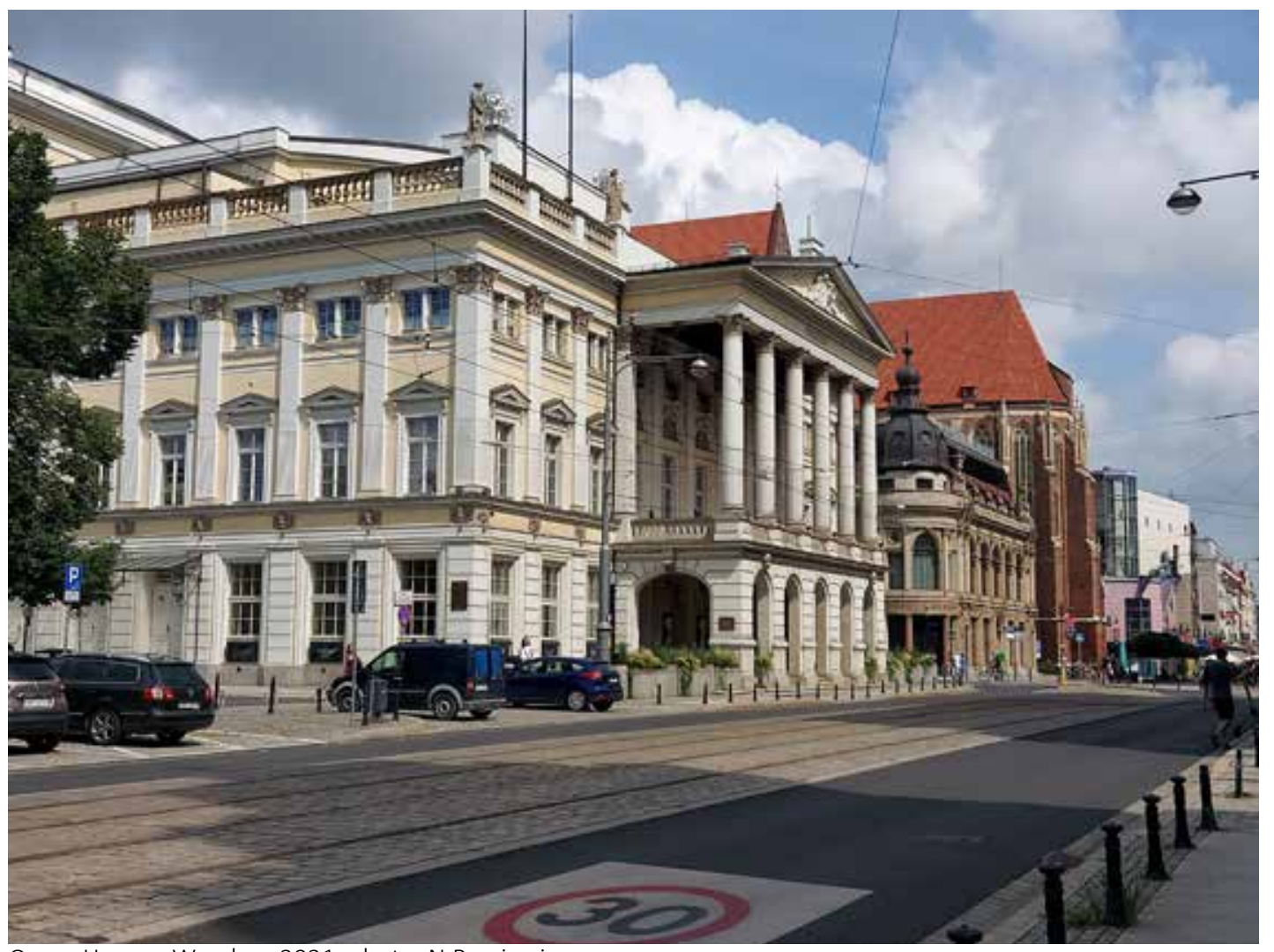

Opera House, Wrocław, 2021, photo: N.Bursiewicz

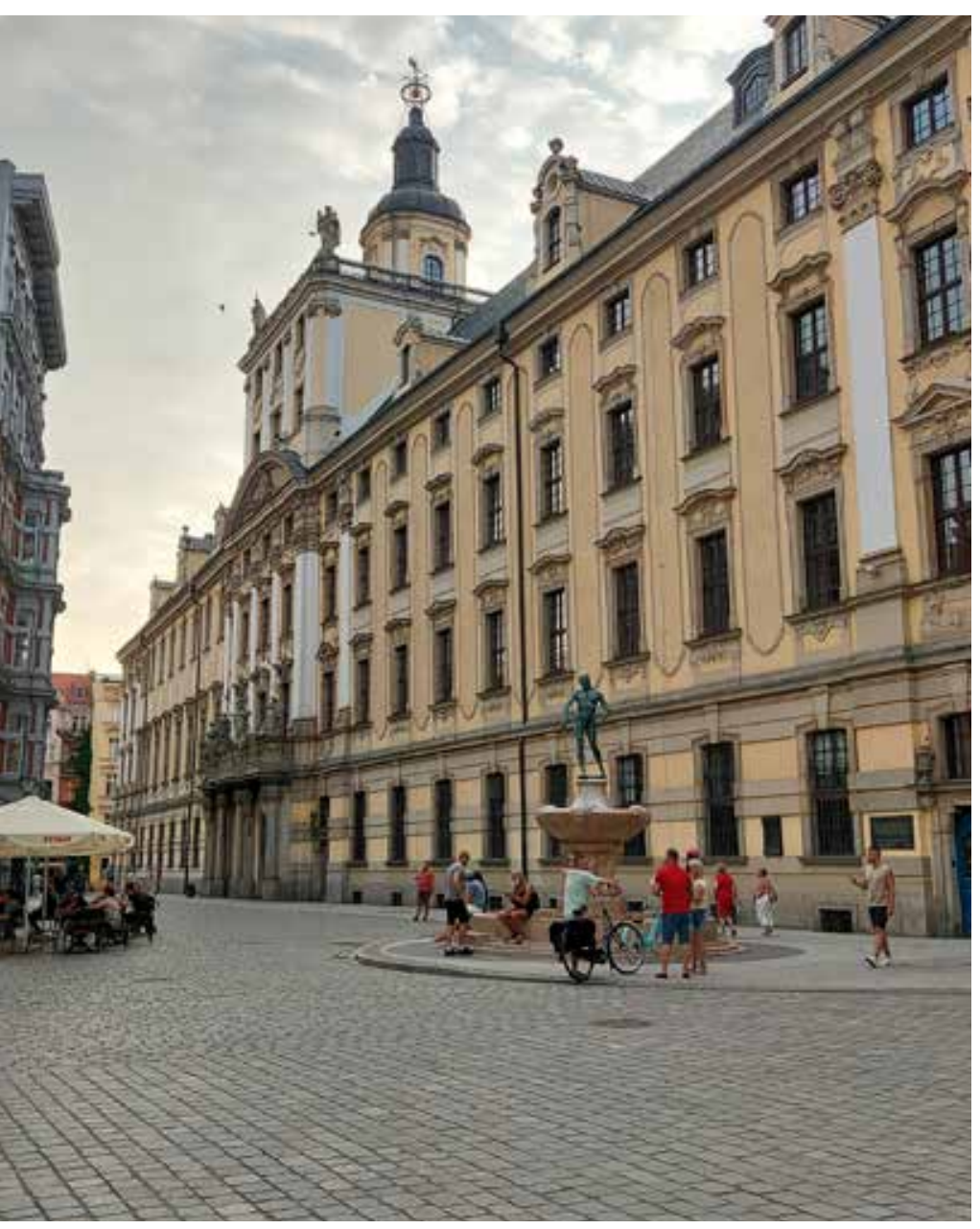

The Main Building of the University of Wrocław, 2021, photo: N.Bursiewicz
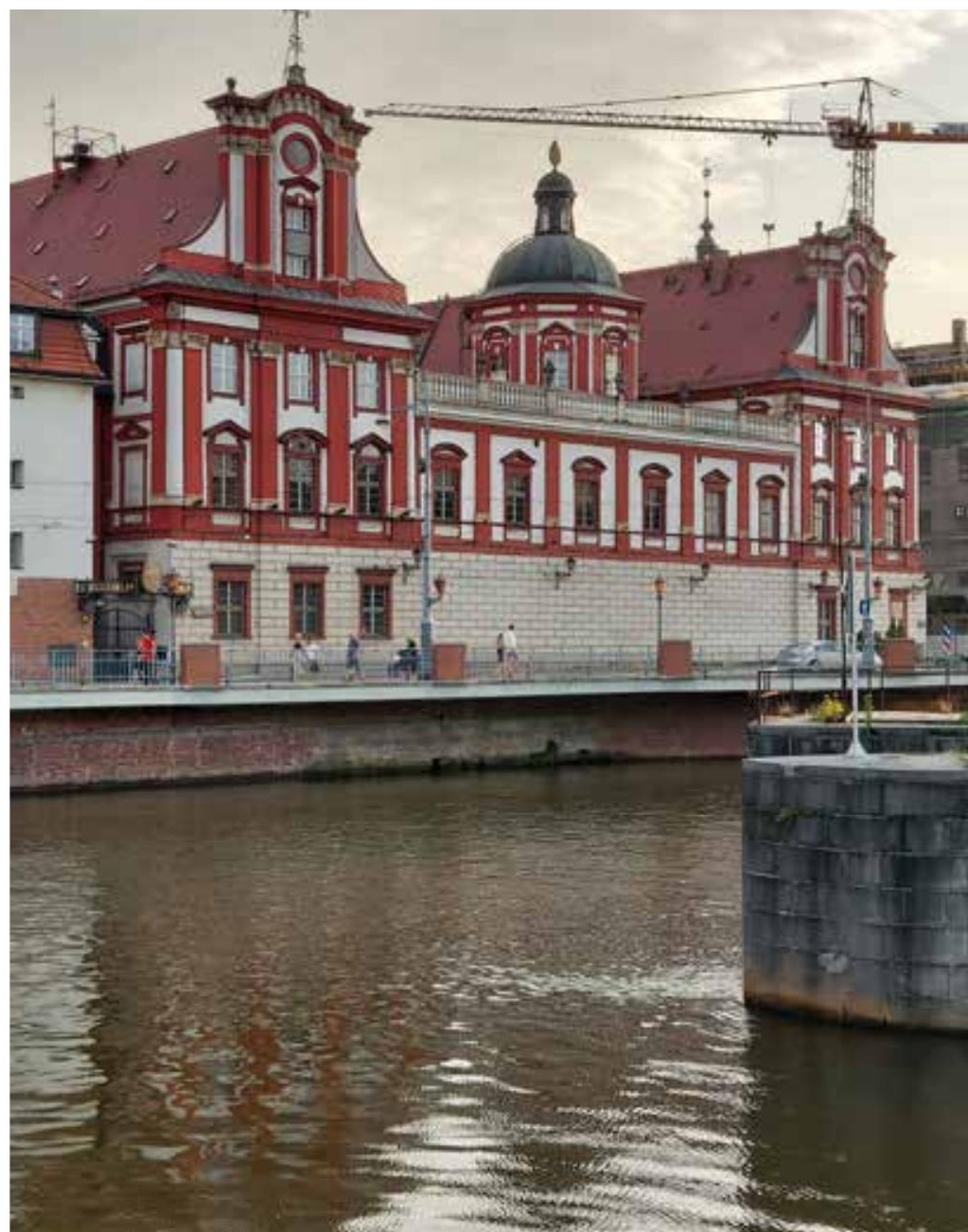

National Ossoliński Institute Wrociaw,2021 if ho to: NBU. Slewicz 


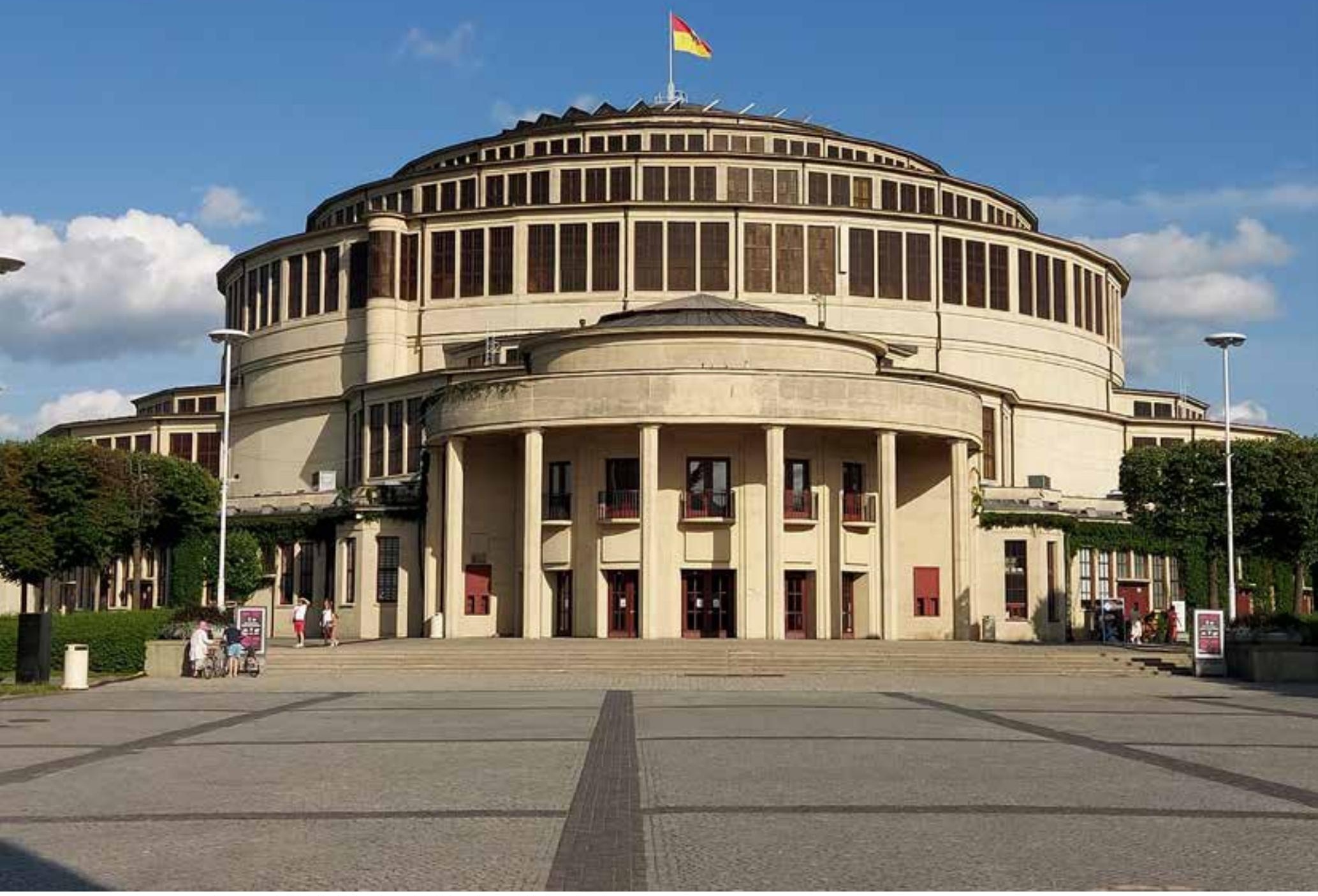

Centennial Hall, Wrocław, 2021, photo: N.Bursiewicz

These data and research results are also consistent with the awards and distinctions received by Wrocław. In 2016, the TripAdvisor portal mentioned Wrocław as the main and only Polish city worth visiting, and in 2018 the city received the European Best Destination Award, winning over 41,000 votes. Among the greatest attractions, the competition organizers mentioned the Market Square, Town Hall, Solny Square, Flower Market, University, Market Hall, and Centennial Hall. Currently Wrocław is considered by tourists to be a modern, cultural city, the main advantage of which lies in the monuments of architecture and construction as well as other tourist attractions. As part of the Multidimensional Ocean Potential of Wrocław study, a nationwide sample ( $n$ total $=1000$ ), the respondents stated that the city has an interesting architecture (35\% definitely yes, 44 rather yes, 47 rather yes) (Pluta et al. 2017: 8-9).

The Old Town in Wrocław receives the greatest attendance. Hence, the most common associations with the city include "colorful tenement houses" located in the market square, the market square, the Solny Square, and the Town Hall. Tourists also associa- 


\section{List of buildings recognized by tourists}

\begin{tabular}{|c|c|c|c|}
\hline & Name & Year of construction & Architect \\
\hline 1. & $\begin{array}{l}\text { Wrocław Old Town (here especially: } \\
\text { Market Square, Town Hall, Solny } \\
\text { Square, tenement houses) }\end{array}$ & $\begin{array}{l}\text { Dating back to XIII } \\
\text { century, with most of } \\
\text { the monuments from } \\
\text { XIV-to XIX century }\end{array}$ & $\begin{array}{l}\text { Poland's official national Historic } \\
\text { Monument }\end{array}$ \\
\hline 2. & Ostrów Tumski (Cathedral Island) & $\begin{array}{l}\text { Most of the } \\
\text { monuments from XIII- } \\
\text { XVIII century }\end{array}$ & \\
\hline 3. & $\begin{array}{l}\text { The ma in building of the University of } \\
\text { Wrocław }\end{array}$ & 1739 & Joha nn Blasius Peintner \\
\hline 4. & National Ossoliński Institute & 1817 & S. Wiedmann, $\mathrm{CH}$. Fischer \\
\hline 5. & White Stork Synagogue & 1829 & Carl Ferdinand Langhans \\
\hline 6. & Railway Station & 1857 & Wilhelm Grapow \\
\hline 7. & Opera House & 1871 & Carl Ferdinand Langhans \\
\hline 8. & Monopol Hotel & 1892 & Karl Grosser \\
\hline 9. & Market Hall (Hala Targowa) & 1908 & Richard Plüddemann \\
\hline 10. & $\begin{array}{l}\text { Four Domes Pavilion (one of the } \\
\text { branches of The National Museum in } \\
\text { Wrocław) }\end{array}$ & 1913 & Hans Poelzig \\
\hline 11. & $\begin{array}{l}\text { Cente nnial Hall (UNESCO World } \\
\text { Heritage Site) }\end{array}$ & 1913 & Max Berg \\
\hline 12. & The "Kameleon" department store, & 1927 & Erich Mendelsohn \\
\hline 13. & $\begin{array}{l}\text { WUWA (Workplace and House } \\
\text { Exhibition) }\end{array}$ & 1929 & $\begin{array}{l}\text { Many architects, among tchem Hans } \\
\text { Scharoun, Adolf Rading }\end{array}$ \\
\hline 14. & $\begin{array}{l}\text { „Manhattan" residential and service } \\
\text { complex }\end{array}$ & 1973 & Jadwiga Grabowska-Hawrylak \\
\hline
\end{tabular}

The table includes a list of historical sites that are most popular among tourists Source: Own elaboration.

\section{List of buildings that most often appear in popular and industry media}

\begin{tabular}{|c|c|c|c|}
\hline & Name & $\begin{array}{l}\text { Year of } \\
\text { construction }\end{array}$ & Architect \\
\hline 1. & $\begin{array}{l}\text { Renoma Commercial Centre } \\
\text { - extension of former "Wertheim" } \\
\text { department store }\end{array}$ & $1930 / 2009$ & $\begin{array}{l}\text { Hermann Dernburg/Maćków Pracownia } \\
\text { Projektowa }\end{array}$ \\
\hline 2. & The Municipal Stadium & 2011 & J.S.K. Architekci \\
\hline 3. & Copernicus Airport Wrocław & 2012 & J.S.K. Architekci \\
\hline 4. & Academy of Fine Arts Wroclaw & 2012 & Pracownia Architektury Glowacki \\
\hline 5. & Sky Tower & 2012 & $\begin{array}{l}\text { Studio Archite ktoniczne } \\
\text { Fold s.c. }\end{array}$ \\
\hline 6. & Capitol Musical Theater & 2013 & KKM Kozień Architekci \\
\hline 7. & Afrykarium-Oceana rium & 2014 & Fabryka Projektowa ArC2 \\
\hline 8. & Silver Tower Center & 2014 & Maćków Pracownia Projektowa \\
\hline 9. & The National Forum of Music & 2015 & $\begin{array}{l}\text { Autorska Pracownia Architketury Kuryłowicz\& } \\
\text { Associates }\end{array}$ \\
\hline 10. & Hydropolis & 2015 & European Copper in Architecture Awards 2017 \\
\hline 11. & Ovo Building & 2016 & Franco-|sra eli firm Gottesman-Szmelcman \\
\hline 12. & Nawa Pavilion & 2017 & Oskar Zieta \\
\hline 13. & Marina III' residential complex & 2019 & Major Architekci \\
\hline 14. & Concordia Design & 2020 & MVRDV, in cooperation with local architect Q2 \\
\hline
\end{tabular}

The table includes a list of contemporary buildings. Source: Own elaboration. 
te Wrocław with churches, especially the cathedral in Ostrów Tumski.. According to the Report of the Commune, other architectural objects constituting an undeniable tourist attraction include, among others The National Museum, Panorama of the Battle of Racławice, Pod Białym Bocianem Synagogue (Raport o stanie GMiny 2019: 151).

The last 30 years have been a period of transformation and change for Wrocław, which, as the current vice-president of the city, Jakub Mazur, emphasizes, is particularly visible in terms of urban planning and architecture (Światowe Media, 2016). On the one hand, revitalization and modernization activities have been undertaken. Wrocław renovated lots of buildings, districts and urban areas. On the other hand new cultural infrastructure was built (e.g. National Forum of Music). Among the "spectacular" investments, Mazur mentions the Music Forum, as well as the main building of the Afrykarium. However, these are not all interesting contemporary architectural realizations.

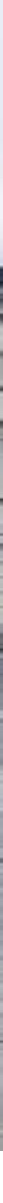

National Forum of Music, Wrocław, photo: N.Bursiewicz (2021) 


\section{The image of architecture of Wrocław in recent tourist commercial}

In the majority of the analyzed, printed materials about Wrocław there are mostly photographs and descriptions of historical architecture. The only exception is a small booklet: "Wrocław. The meeting place", where many modern buildings were mentioned (Klimek et. al. 2018). There is also a plan- city's brochure, prepared as part of the European Best Destination 2018 by the City and Tourism Promotion Office, where one can find short description of the National Forum of Music and a photo of the Silver Tower.

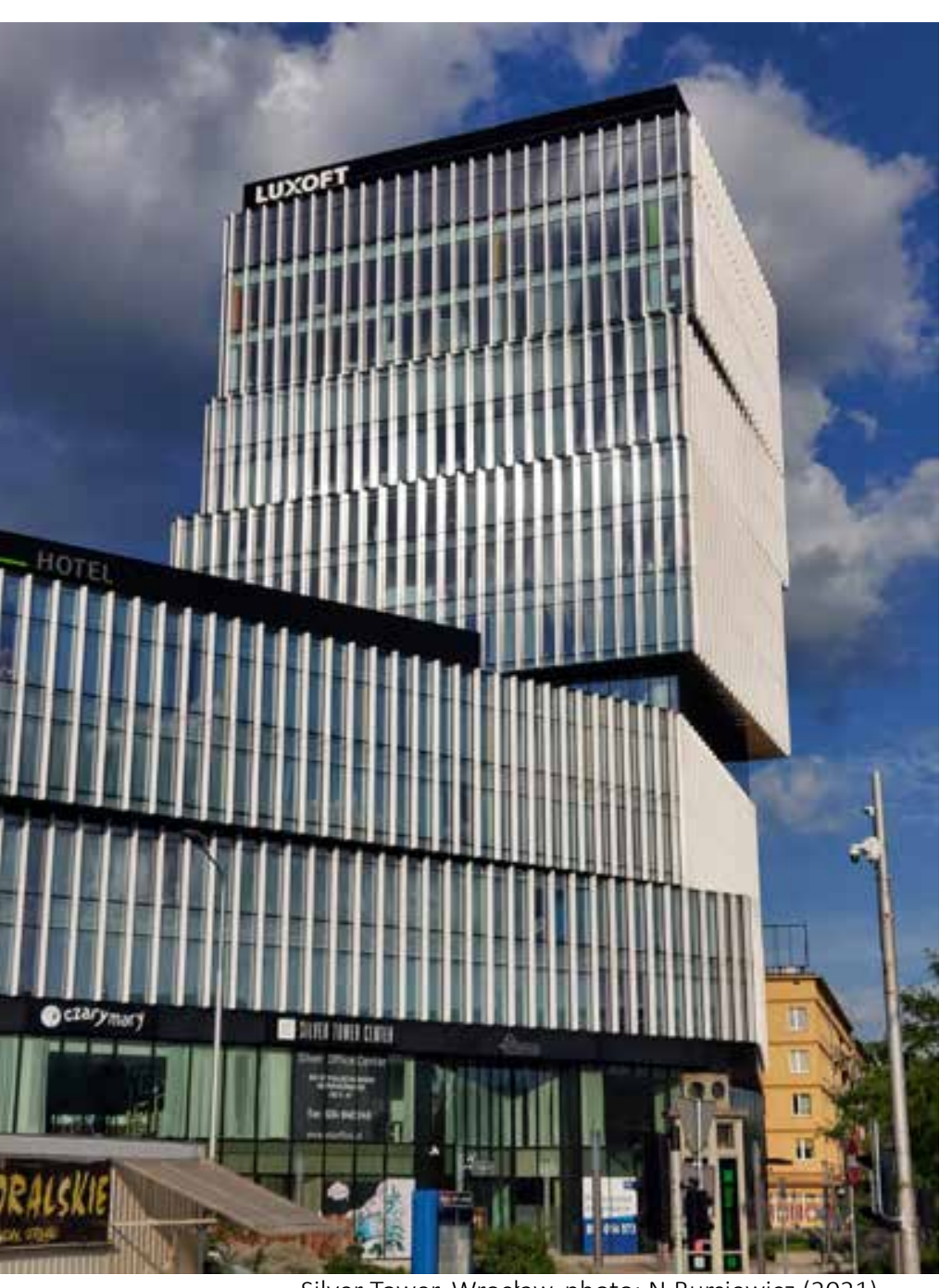

Silver Tower, Wrocław, photo: N.Bursiewicz (2021)
On official portals of Wrocław, historical architecture from the Middle Ages to the 20th century is primarily mentioned (https://visitwroclaw.eu/en/architecture). In the film presenting Wrocław as the European Capital of Culture 2016, only the Centennial Hall and WUWA were shown from the "newer" facilities (Architektura W ... 2015]). Sky Tower however is shown many times at the promotional spot (Spotkajmi Sie ..., 2020).

The publications and promotional materials of the City Hall also include the $\mathrm{Na}$ tional Forum of Music, Hydropolis (which has so far received 13 awards and distinctions for, among others, tourist attractiveness and architecture (Raport 2019: 151]), Afrykarium and the Wrocław Stadium (Biuletyn ...; VisitWroclaw, 2018).

Among Wrocław universities, contemporary architecture (Sky Tower, Stadium) is shown in its materials mainly by the University of Economics (Universytet Ekonomiczny we Wroclawi, 2017). In nationwide materials, if there is any aspect related to contemporary architecture, it is most often Music Forum, Hydropolis, Sky Tower, Stadium or Afrykarium (Pomysl Na ..., 2017; Polska Jest ..., 2016; Welcome to ..., 2019]. 


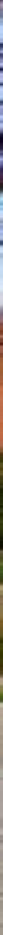




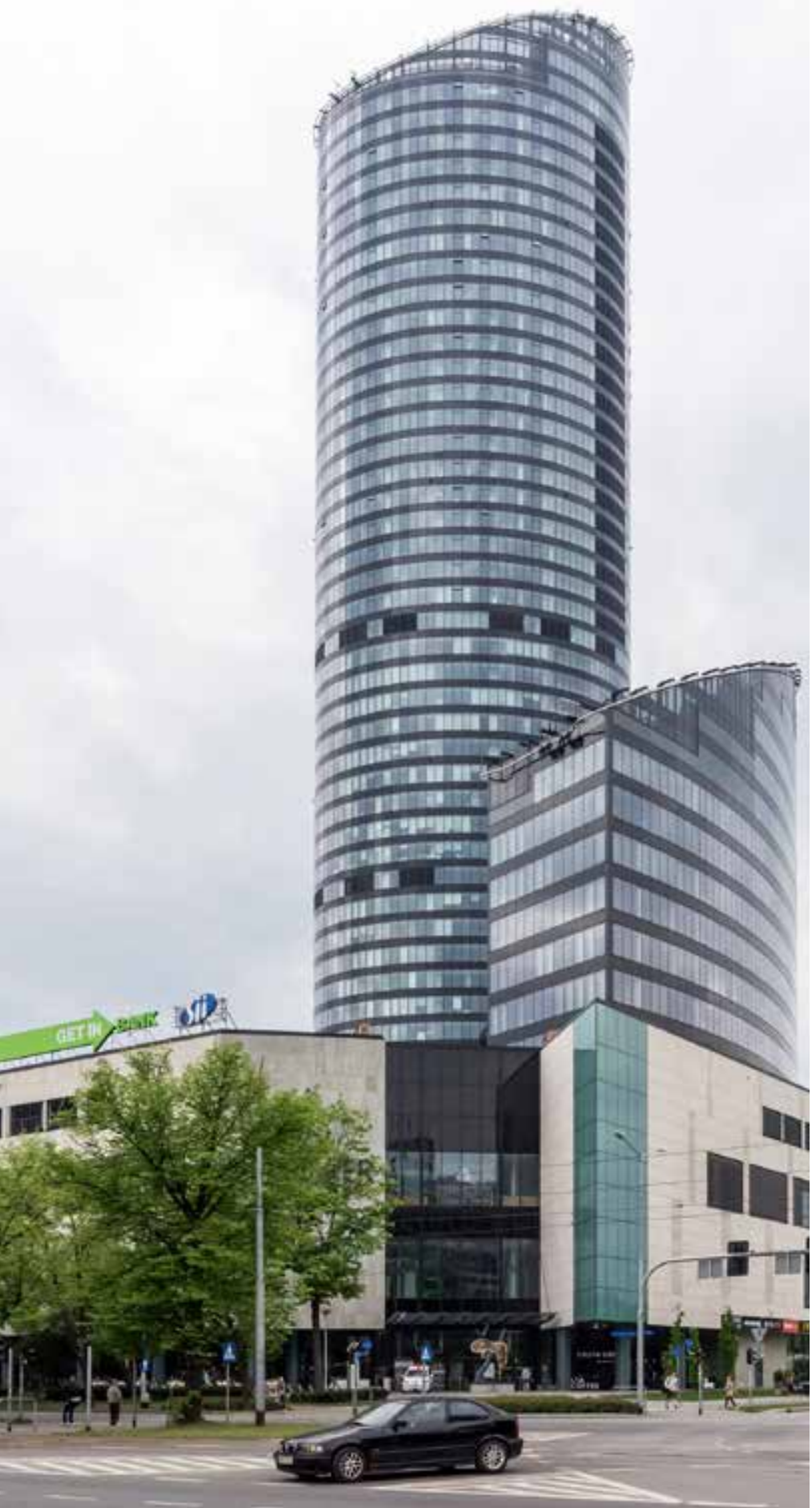

Sky Tower, Wrocław, photo: Jacek Halicki (https:// commons.wikimedia.org)
On travel, thematic and social portals, although descriptions of historical architecture dominate (wroclawguide; tripadvisor; travelsewhere' theculturetrip), contemporary architecture is mentioned much more often than in official materials, especially on YouTube. In this case, Oskar Zięta's NAWA, Wroclavia, Music Forum, Afrykarium, Hydropolis, Sky Tower, dominate (Wrocław in 2 minutes 2018). The article in Vogue mentions the OVO as "the boldest addition to Wroclaw's buzzing architectural scene" and the National Music Forum, being "a place of astonishing architecture inspired in part by a violin's sound box (Burshten, 2016).

The growing importance of Wrocław in the area of contemporary architecture is revealed during the analysis of industry portals, both domestic and foreign. The Archdaily featured articles on: Hydropolis, OVO, Silver Tower Center, Academy of Fine Arts, City Stadium, and Concordia Design (Archdaily). Dezeen mentioned Concordia Design (Dezeen).

Both portals, as well as the DETAIL magazine, also wrote about the award-winning sculpture-pavilion - NAWA by Oskar Zięta, which in 2019 was nominated for the European Union Prize for Contemporary Architecture - Mies van der Rohe Award [detail]. Wallpaper wrote about the futuristic in shape- OVO, which houses the Double Tree by Hilton [Wallpaper]. Designboom took note of Concordia Design as "building that opens up to visitors in all directions", Afrykarium that "alludes to the curvature of a ship", Marina that 


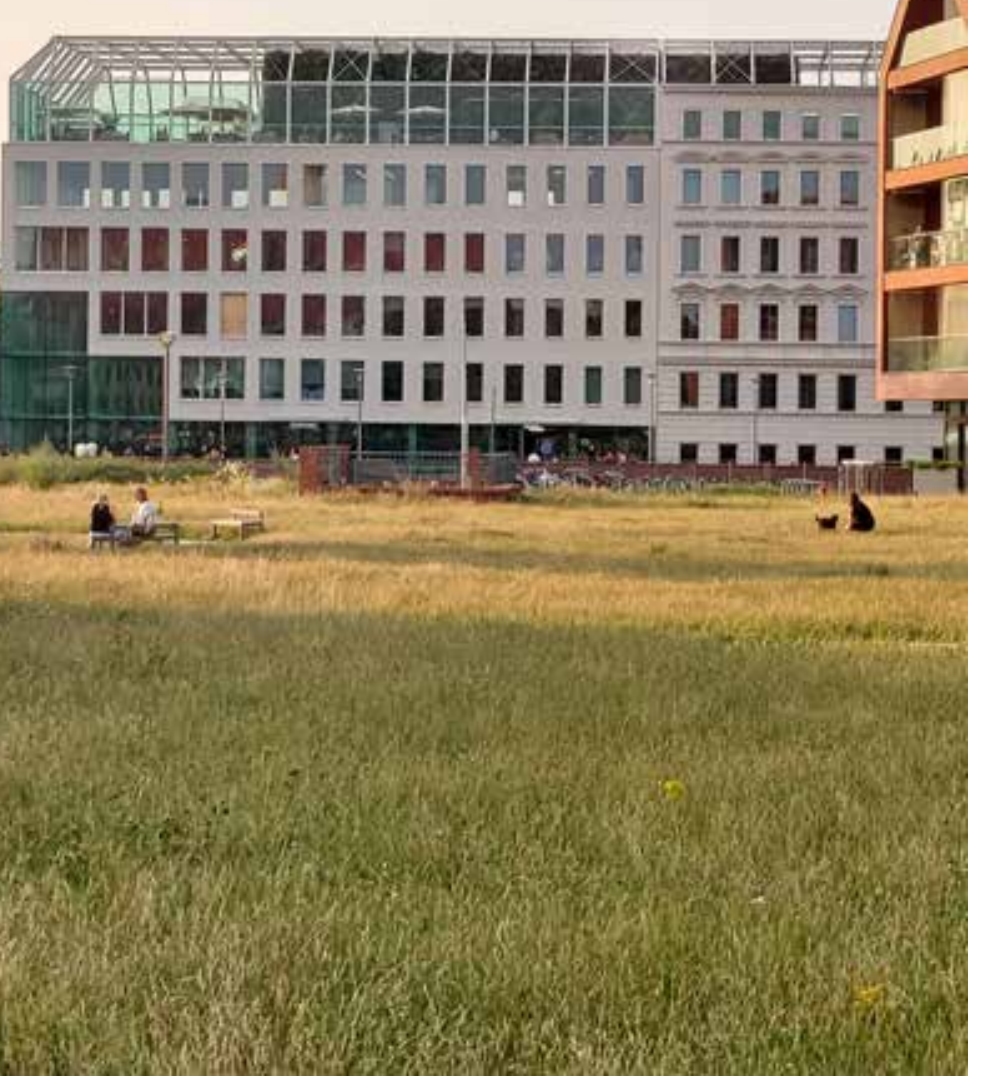

Concordia Design, Wrocław, photo: N.Bursiewicz (2021)

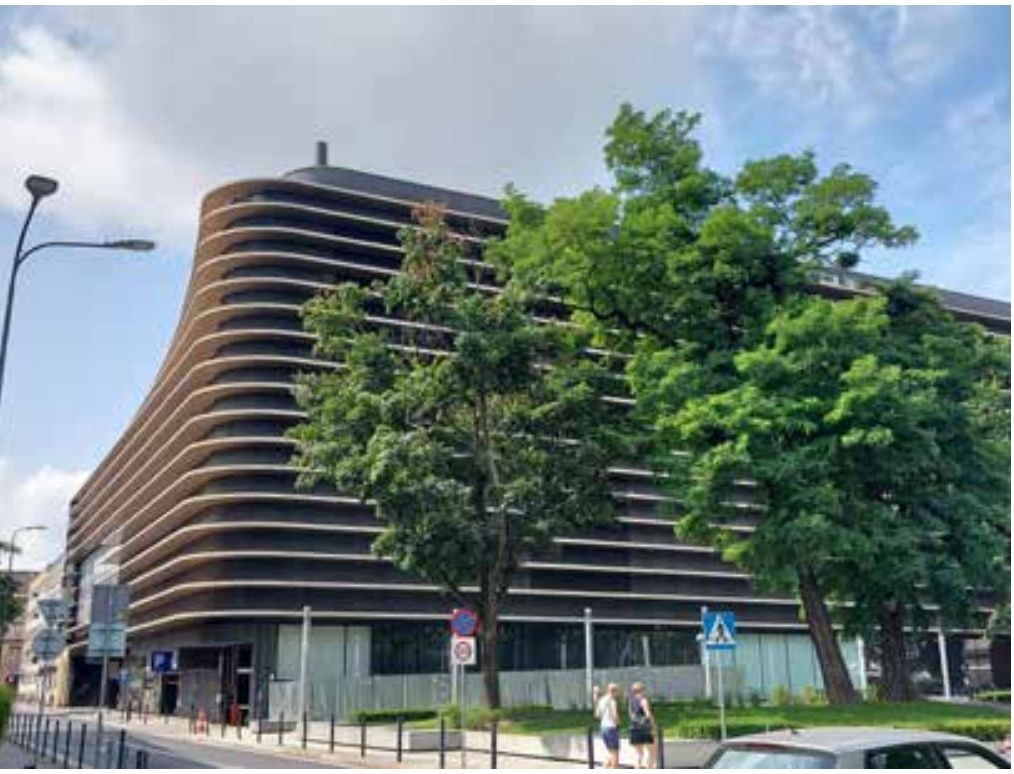

Renoma Department Store, Wrocław, photo:

N.Bursiewicz (2021) "aims to create a coherent urban layout along the waterfront", OVO that "establishes a new vision of urban living within the polish city" (Designboom).

Uncube Magazine devoted the entire issue no. 31 to Polish architecture. It included three objects from Wrocław: the Academy of Fine Arts, the Stadium and the so-called "Manhattan" which "woven concrete façades hold echoes of the work of the Japanese Metabolists" (Uncubemagazine). The film prepared by the Polish magazine Architektura Murator in cooperation with local government authorities, and presenting the transformations that have taken place in the city's architecture over the last quarter century, showed Sky Tower, Music Forum, Renoma, Stadium, Airport, Nowe Żerniki, new University Library (Polska Dojrzalosc, 2017). As part of the Strefa Przestrzeni Channel - devoted to architecture, urban planning and landscape, the Music Forum, Capitol, Renoma and the airport were discussed in detail (Strefa Przestrzeni).

Most of the presentations of Wrocław's contemporary architecture can be found on Instagram. Both on the official profile wroclaw_official, as well as numerous travelers' and local people's profiles: kocham.wroclaw or wroclovers repeatedly post pictures of Sky Tower, Stadium, Ovo, "Manhattan", National Forum of Music, Silver Tower Center and Renoma Department Store. 


\section{Conclusions. Contemporary architecture of Wrocław - hidden potential}

The results of the research conducted by the author show that architecture can be an extremely attractive product for domestic and international tourists but it is rarely used by the City Hall as well as other local institutions. Thanks to numerous architectural investments, including such objects as the futuristic shape of OVO, Wrocław is consistently gaining attention from the world's media, which shapes the new, tourist image of the city. Nevertheless, still, it is not contemporary but historical architecture that is the main destination for tourists. Thus, the Town Hall, the Cathedral and the Centennial Hall are the most recognizable and vivid architectural symbols of the city itself.

The analysis of official city websites as well as social media and printed materials showed that the city, despite having very good and attractive contemporary architecture, hardly uses it in promotional or marketing materials. Presentations of historical architecture prevail in various forms of presenting the city's tourist offer, i.e. in folders, on internet portals or in films. Sky Tower, Afrykarium or Hydropolis appear only marginally. Taking into account the city's resources and the potential hidden in the latest urban construction, greater efforts should be made to systematically shape the image of the city in relation to contemporary architecture. Especially because, according to the concept of Haila, investments in icon buildings constitute an important element of the urban marketing game (Haila, 1997). However, their promotion is also equally important. Meanwhile, as Siegfried Kracauer pointed out, tourists are prepared for foreign places through the perusal of illustrated magazines (Kracauer, 1995: 66). Therefore blogs, social media and advertising materials play such a crucial role. Failure to take this element of promotion into account may however be due to several factors, including: lack of awareness of the potential of contemporary architecture, ignorance, fear of misunderstanding and criticism. Usually, what previous generations wrote down and created evokes admiration, while what is currently created often gives rise to heated discussions and opposition (Jalowiecki, 2007: 151-152).

On the other hand, from the point of view of the history of architecture, almost every new object, which with time became an icon, acted on the basis of a surprise, breaking with canons or context, as well as destroying the adopted aesthetic order. Therefore, initially, it encountered social resistance. In the case of Poles, the matter is even more complex, because the last two generations were deprived of the possibility of everyday contact with works of contemporary architecture, and therefore do not know the aesthetic code that would allow them to evaluate its artistic expression. Hence, as emphasized by prof. Jałowiecki, there is so much kitsch and mediocrity in the current landscape (Jalowiecki, 2007: 152). 
Contemporary architecture, however, begins to penetrate the landscape of Polish cities in small steps, allowing more and more people to deal with it. As a result, there is a growing awareness of its importance in creating a modern, progressive city, as well as in building a competitive advantage. Because not only historical, but also contemporary architecture can be an image of „cultural and commercial achievements of the city and the nation-state" (Julier, 2000: 120 -121). Therefore the role of architecture in branding a city seems truly substantial. Information focused on eyesight enhances the power of the message, that is why the more presentations of contemporary architecture appear in promotional materials, the more beneficial it may be for its image, especially since it is a promotion without words, i.e. the one with the greatest impact. In the interpretation of the author, who is a Wrocław citizen, Wrocław is not only a meeting place in the social sense, but also spatially. It is because styles of different epochs, including recent ones, meet there. The architecture is complemented by the image of the city that has been shaped for over a dozen years, making it attractive. The analysis of the conducted survey research confirmed this thesis.

\section{References}

ADAMUS-MATUSZYNSKA, A., \& DZIK P. (2019). 'Welcome signs' in public space: separation and identity. On the W@terfront, 61(4), 3-16. https://doi.org/10.1344/waterfront2019.61.6.4

ANHOLT, Simon (2007). Tożsamość konkurencyjna. Nowe spojrzenie na markę. Warszawa: Instytut Marki Polskiej.

ANHOLT, Simon. (2010). Places: Identity, Image and Reputation. Palgrave Macmillan Artifacts: Views of the Corporate Landscape, New York: Aldine de Gruyter, 41-67.

ASHWORTH, Gregory J. (2009) 'The instruments of place branding: how it is done?' [in:] European Spatial Research and Policy, vol. 16, nr. 1, 9-22.

BERG, Per-Olof; KREINER, Kristian (1990), Corporate architecture: 'Turning Physical Settings into Symbolic Resources' in GAGLIARDI, P. Symbols and Artifacts. Volume 24 in the series de Gruyter Studies in Organization, pp 41-68 . https://doi.org/10.1515/9783110874143.41

BURSHTEN, Karen (2016). Why You Should Visit Wroclaw-The Polish City You've Never Heard Of (And Probably Can't Pronounce) https://www.vogue.com/article/wroclaw-poland-travel-guide-under-theradar.

CORBOS, Răzvan-Andrei; POPESCU, Ruxandra Irina (2011).' Museums, marketing, tourism and urban development. The British Museum - a successful model for romanian museums'. [in:] Management \& Marketing Journal 9 (2), 303-314.

FLOREK, Magdalena (2013). Podstawy marketing terytorialnego

GLIŃSKA, Ewa; FLOREK, Magdalena; KOWALEWSKA, Anna (Eds.), (2009). Wizerunek miasta. Od koncepcji do wdrożenia, Warszawa: Wolters Kluwer Polska.

HAILA, Anne (1997) 'The neglected builder of global cities', [in:] O. Kalltorp, I. Elander, O. Ericson, M. Franzen (Ed) Cities in transformation - transformation in cities. Social and symbolic change of urban space, Ashgate Publishing Limited, 51-64.

JAŁOWIECKI, Bohdan (2007). Globalny świat metropolii. Warszawa: Wydawnictwo Naukowe Scholar.

JULIER, Guy. (2000) The Culture of Design.London: Sage. 
KAVARATZIS, Mihalis; ASHWORTH, G. J. (2005). 'City branding: an effective assertion of identity or a transitory marketing trick?' [in:] Tijdschrift voor Economische en Sociale Geografie 2005, Vol. 96 , No. 5, 506-514.

KLIMEK, Stanisław, MACIEJEWSKA, Beata (2018). Wrocław. The meeting place. Wrocław: Via Nova.

KRACAUER, Siegfried. (1995) The mass ornament: Weimar Essays, translated by Thomas Y. Levin. Cambridge.

Leipzig Charter on Sustainable European Cities 2007.

OCKMAN, Joan; FRAUSTO, Salomon (2005). Architourism. New York.

PLUTA, Jacek; BŁASZCZYK, Mateusz; BANASZAK, Ewa; KAJDANEK, Katarzyna (2017). Wizerunek Wrocławia w perspektywie ESK Wrocław 2016. Raport z ogólnopolskich badań sondażowych. Instytut Socjologii Uniwersytet Wrocławski; Biuro Festiwalowe IMPART.

PONZINI, Davide; BIANCHINI, Franco, GEORGI-NERANTZIA TZORTZI Julia, SANETRA-SZELIGA, Joanna (Eds.) (2020). Mega-Events and Heritage: The experience of five European cities. Kraków: Międzynarodowe Centrum Kultury. Raport o stanie gminy 2019 Wrocław https://www.wroclaw.pl/portal/files/dokumenty/30060/Raport_o_stanie_gminy_2019.pdf

REMESAR, Antoni. (2016). 'New Urban Decorum? Aesthetics To and Fro'. In GRALIŃSKA-TOBOREK;A -KAZIMIERSKA-JERZYK, W (ED) Aesthetic Energy of the City (pp. 19-54). Wydawnictwo Uniwersytetu Łódzkiego (Łódź University Press). https://wydawnictwo.uni.lodz.pl/produkt/aesthetic-energy-of-thecity/

REMESAR, A. (2020). 'From drinking fountains to promenades. Water as artistic medium?'. On the W@ terfront, 62(1), 3-84. https://doi.org/10.1344/waterfront2020.62.6.1

RIEGL, Aloïs. (1903). Der Modrne Denkmalkultus. Sein Wessen und seine Entstechung (1987th Spanish ed.). Visor.

ROUBA, Rafał (2012). 'Promocja miast w XXI wieku poprzez ikony architektoniczne - przykład Krzywego Domku w Sopocie', [in:] Studia Miejskie Tom 7, 91-105.

SCHWARZER, Mitchell, 'Architecture and mass tourism w Architourism' settings into symbolic resources. [in:] GAGLIARDI, P. Symbols and Artifacts. Volume 24 in the series de Gruyter Studies in Organization, pp 12-33 . https://doi.org/10.1515/9783110874143.41

SITTE, Camilo. (1889). L'art de bâtir les villes: Notes et réflexions d'un architecte (1910th ed.). Ed. Atar. https://gallica.bnf.fr/ark:/12148/bpt6k744025?rk=21459;2

TEMELOVA, J. (2004) 'Contemporary Buildings in City Promotion: Attributes and Foundation of HighProfile Structures. The case of Prague and Helsinki'. RTN Urban Europe series, number 10/2004

Internet Sources:

Archdaily: https://www.archdaily.com/tag/wroclaw [13.05.2021].

Architektura w Europejskiej Stolicy Kultury Wrocław (2016). Strefa Kultury Wrocław: https://www.youtube.com/watch?v=DEKZqDLutKk

Biuletyn Informacji Pulicznej UM Wrocław, https://bip.um.wroc.pl/artykul/638/23235/atrakcje-turystyczne-wroclawia [13.05.2021].

Designboom: https://www.designboom.com [13.05.2021].

DETAIL https://www.detail-online.com/article/ultra-light-steel-construction-bionic-parametric-inflated-34424/ [13.05.2021].

Dezeen: https://www.dezeen.com/tag/poland [13.05.2021].

Polska dojrzałość: jak w ciągu ostatnich 25 lat zmienił się Wrocław (2017) Architektura Murator: https:// www.youtube.com/watch?v=40OPk_Whdag [13.05.2021].

Polska jest piękna. Wrocław (2016). Polska zachwyca: https://www.youtube.com/watch?v=WI4Zn8PLLlo [13.05.2021].

Pomysł na weekend: Wrocław (2017). National Geographic Magazine Poland: https://www.youtube. 
com/watch?v=xYj5vgX_On0 [13.05.2021].

Spotkajmy się we Wrocławiu! (2020). VisitWroclaw: https://www.youtube.com/watch?v=eLGq6pXUeu4 [13.05.2021].

Strefa Przestrzeni- Zone of Expanse https://www.youtube.com/channel/UCvIPAXdID7yMni7095YeAoQ [13.05.2021].

Światowe media piszą o Wrocławiu (2016). Telewizja Echo 24: https://www.youtube.com/ watch?v=Clj0QiTQ9ZI [13.05.2021].

The Culture Trip: https://theculturetrip.com/europe/poland/articles/the-top-10-things-to-do-and-seein-wroc-aw/ [13.05.2021].

Travelsewhere: https://www.travelsewhere.net/wroclaw/ [13.05.2021].

Trip Advisor: https://www.tripadvisor.co.uk/Attractions-g274812-Activities-c47-t3-Wroclaw_Lower_Silesia_Province_Southern_Poland.html [13.05.2021].

Uncubemagazine: $\quad$ https://www.uncubemagazine.com/magazine-31-15285563.html\#!/page2 [13.05.2021].

Uniwersytet Ekonomiczny we Wrocławiu (2017). https://www.youtube.com/watch?v=OX8QQrTBfqM [13.05.2021].

Wallpaper https://www.wallpaper.com/travel/poland/wroclaw/ [13.05.2021].

Welcome to Poland! (2019). Polska zachwyca: https://www.youtube.com/watch?v=mv689d8mvZo [13.05.2021].

Wrocław in 2 minutes (2018) Jumper, Amazing Poland Trip: https://www.youtube.com/ watch?v=tCiLgbHGhnw [13.05.2021].

WrocławGuide.com: https://www.wroclawguide.com/en/the-25-most-impressive-buildings-in-wroclaw/ [13.05.2021].

https://www.europeanbestdestinations.com/european-best-destinations-2018/ [09.05.2021].

\section{Received: 18/06/2021 Evaluated 18/07/2021 Published 10/09/2021}

\section{Natalia Bursiewicz}

Pedagogical University of Krakow

natalia.bursiewicz@up.krakow.pl

https://orcid.org/0000-0002-2037-0100

Assistant professor at the Institute of History and Archives of the Pedagogical University of Krakow. She has a degree in Art History and Iberian Studies from Wrocław University. Doctoral thesis on the evolution of a place in Spain within a historic city was defended with honors in May 2017. He currently teaches in the field of art and architecture history, as well as historical tourism and cultural heritage. 